\title{
Odporność korozyjna złączy spawanych stopu aluminium AW 7020
}

\section{Corrosion resistance of the aluminium alloy AW 7020 welds}

\section{Streszczenie}

Celem pracy była ocena odporności korozyjnej złączy spawanych stopiu aluminium AW 7020 z zastosowaniem trzech rodzajów spoiwa: jednego z krzemem oraz dwóch z magnezem. W wyniku przeprowadzonych badań zaobserwowano istotne zmiany w parametrach elektrochemicznych dla poszczególnych mikroobszarów wykonanych złączy spawanych. Wyniki wykazują niedostateczną ochronę anodową badanych złączy spawanych.

\section{Abstract}

The aim of this study was to evaluate the corrosion resistance of the welded joints of the alloy AW 7020 made with the use of three types of the filler metal: one with silicon and two with magnesium. Significant changes in the electrochemical parameters for each microzones of the welds were obtained. Results show that it is need to ensure the anodic protection of the welds.

\section{Wstęp}

W stopach aluminium serii 7000 podstawowym pierwiastkiem stopowym jest cynk występujący do zawartości $9 \%$ wag. Prawie wszystkie stopy tej serii zawierają również $\mathrm{Mg}$ (< $4 \%$ wag.), a w większości występuje także Cu (<3\% wag.) [1]. Stop AW 7020 należy do stopów o ograniczonej zawartości miedzi. Stopy aluminium $\mathrm{z}$ cynkiem dzięki wydzielającej się fazie $\mathrm{Zn} \mathrm{n}_{2} \mathrm{Mg}$ należą do stopów umacnianych cieplnie. $Z$ tego względu ich właściwości wytrzymałościowe zależą od parametrów obróbki cieplnej. Przesycanie i sztuczne starzenie pozwalają na uzyskanie wartości wytrzymałość na rozciąganie $R_{m}$ wynoszącej ponad $400 \mathrm{MPa}$ [2]. Wprowadzenie do aluminium pierwiastków stopowych pozwala na istotną poprawę jego właściwości mechanicznych, jednak wywołane tym tworzenie się faz o odmiennych właściwościach elektrochemicznych od roztworu stałego na bazie aluminium, wiąże się $z$ pogorszeniem ich odporności na korozję elektrochemiczną.

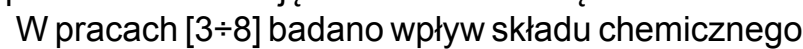
i faz międzymetalicznych występujących w strukturze

Dr. inż. Marzena M. Lachowicz - Politechnika Wrocławska. stopu na odporność korozyjną stopów serii 7000. Stwierdzono, że najkorzystniejsze właściwości elektrochemiczne wykazują stopy o bardzo niskiej zawartości miedzi. W przypadku występowania w ich składzie chemicznym tego pierwiastka, większość z nich wykazuje bardzo umiarkowaną odporność na różne typy korozji elektrochemicznej. Oprócz składu chemicznego, na odporność korozyjną stopów aluminium istotny wpływ wywiera również zastosowana obróbka cieplna. Odpowiedni dobór warunków sztucznego starzenia może znacznie przyczyniać się do poprawy ich odporności na korozję [1]. W pracy [9] wykazano, że wydzielanie się fazy $\mathrm{Zn}{ }_{2} \mathrm{Mg}(\mathrm{n})$ powoduje przesunięcie potencjału $\mathrm{E}_{\text {kor }} \mathrm{w}$ kierunku wartości katodowych, co związane jest z bardziej ujemną wartością potencjału korozyjnego tej fazy w stosunku do osnowy. Nie bez znaczenia dla zachowania korozyjnego pozostaje również wielkość ziarna roztworu stałego $a$. Stop AW 7475 o strukturze nanokrystalicznej charakteryzował się niższymi wartościami potencjału korozyjnego i prądu korozyjnego niż próbka o mikrometrycznej wielkości ziarna [8]. Szczególnie dużą wrażliwość aluminium i jego stopy wykazują w przypadku działania jonów chlorków, prowadzących do niszczenia tworzącej się na ich powierzchni warstwy pasywnej.

Badania nad spawalnością stopów serii 7000 opisano w $[10 \div 16]$. Podstawowym problemem dotyczącym 
spawalności stopów aluminium jest ich duża skłonność do tworzenia pęknięć gorących, wynikająca z ich wysokiego przewodnictwa cieplnego, skurczu objętościowego oraz zjawiska likwacji. Z tego względu konstrukcje spawane wykonywane są głównie ze stopów serii 5000 i 6000. Autorzy realizowanych badań zwracają uwagę na tendencję stopów serii 7000 do obniżenia twardości w strefie wpływu ciepła $[10,12 \div 14,16]$. Zmiany te związane są z koagulacją faz umacniających stop wydzieleniowo.

Celem pracy była ocena odporności korozyjnej złączy spawanych stopu AW 7020 z zastosowaniem trzech spoiw: jednego z krzemem oraz dwóch $z$ magnezem. Zmiany w mikrostrukturze, ze względu na wysoką temperaturę procesu spawania, mogą prowadzić do przestarzenia stopu, co wpłynie na odporność korozyjną. Jednocześnie zastosowanie spoiw o odmiennym składzie chemicznym wiąże się również ze zmianą potencjału w obszarze spoiny w odniesieniu do materiału rodzimego, co nie pozostaje bez wpływu na odporność korozyjną spawanego materiału.

\section{Materiał i metodyka badań}

Materiał do badań stanowił stop aluminium z cynkiem przeznaczony do przeróbki plastycznej AW 7020. Skład chemiczny badanego materiału zestawiono w tablicy I, natomiast jego mikrostrukturę pokazano na rysunku 1 . W toku wstępnych badań materiałowych ustalono kierunek walcowania blach o grubości $10 \mathrm{~mm}$, dla których wykonano złącza doczołowe poprzeczne do kierunku walcowania. Jako materiał dodatkowy zastosowano trzy gatunki stopów: AIMg5 (elektroda 1), AIMg4,5Mn (elektroda 2) i AISi5 (elektroda 3) objętych PN-EN ISO 18273:2007. Spawano metodą GTAW prądem przezmiennym o natężeniu 230 A. Starzenie naturalne przebiegało w temperaturze pokojowej przez okres ok. 1 miesiąca.

W celu przeprowadzenia badań makro- i mikroskopowych złączy spawanych wykonano przekroje przez całą grubość blachy obejmujące spoinę, strefę wpływu ciepła oraz materiał rodzimy. Badania mikroskopowe wykonano na mikroskopie świetlnym Neophot 32 po trawieniu chemicznym odczynnikiem Mi1Al (PN-75/H-04512).

Elektrochemiczne pomiary stałoprądowe służące do oceny odporności korozyjnej przeprowadzono metodami obejmującymi pomiar potencjału obwodu otwartego $E_{0}$ i zarejestrowanie zależności $i=f(E)$ podczas badań polaryzacyjnych w trójelektrodowym układzie pomiarowym. Układ pomiarowy całkowicie

Tablica I. Skład chemiczny badanego stopu Table I. Chemical composition of tested alloy

\begin{tabular}{|c|c|c|c|c|c|c|c|c|c|c|}
\hline Pierwiastek & $\mathrm{Zn}$ & $\mathrm{Mg}$ & $\mathrm{Mn}$ & $\mathrm{Fe}$ & $\mathrm{Cr}$ & $\mathrm{Si}$ & $\mathrm{Zr}+\mathrm{Ti}$ & $\mathrm{Zr}$ & $\mathrm{Cu}$ & $\mathrm{Al}$ \\
\hline $\begin{array}{c}\text { Zawartość, } \\
\% \text { wag. }\end{array}$ & 4,0 & 1,4 & 0,40 & 0,30 & 0,11 & 0,13 & 0,19 & 0,16 & ślady & reszta \\
\hline
\end{tabular}

zautomatyzowany składał się z naczynka pomiarowego, potencjostatu Atlas 0531 Elektrochemical Unit \& Impedance Analyser oraz sterownika komputerowego. Elektroda pomocnicza była wykonana ze stali austenitycznej, natomiast jako elektrodę odniesienia zastosowano nasyconą elektrodę $\mathrm{Ag} / \mathrm{AgCl}$. Próbki do badań korozyjnych były szlifowane, a następnie polerowane bezpośrednio przed pomiarem. Powierzchnia elektrody badanej (próbki) wynosiła $0,785 \mathrm{~cm}^{2}$. Próbki pobrane z połączeń spawanych zostały wycięte ze środka spoiny. Dla każdej spoiny wykonano trzy próbki, na których prowadzono pomiary. Przed rozpoczęciem pomiaru każda próbka przebywała przez $30 \mathrm{~min}$ w $5 \%$ roztworze $\mathrm{NaCl}$ o temperaturze $20^{\circ} \mathrm{C}$ w celu stabilizacji potencjału stacjonarnego, po czym była poddawana w tym samym roztworze polaryzacji w kierunku anodowym $\mathrm{z}$ prędkością $\mathrm{dE} / \mathrm{dt}=1 \mathrm{mV} / \mathrm{s}$. Wartość $\mathrm{pH}$ zastosowanego roztworu korozyjnego wynosiła 7,5. Wartość początkową potencjału badań potencjodynamicznych wyznaczono w oparciu o wartości potencjału obwodu otwartego $E_{o}$, przyjmując wartość o ok. $200 \mathrm{mV}$ niższą. Wartości prądu I ${ }_{k o r}$, potencjału korozji $E_{k o r}$ oraz oporu polaryzacji $R_{p}$ wyznaczono metodą Sterna, a zużycie korozyjne wg wzoru $V_{p}=(M / z \cdot F \cdot \rho) \cdot I_{\text {kor }} \mathrm{mm} /$ rok, gdzie: $M$ - masa molowa metalu, z - liczba elektronów uczestnicząca w reakcji elektrodowej, F - stała Faradaya, $\rho$-gęstość metalu. Zastosowanie następujących danych dla aluminium: $\mathrm{M}=27 \mathrm{~g} / \mathrm{mol}, \mathrm{z}=3$ dla reakcji $\mathrm{Al} \rightarrow \mathrm{Al}^{3+}+3 \mathrm{e}^{-}, \mathrm{F}=96484,33 \mathrm{C} / \mathrm{mol}, \rho=2,70 \mathrm{~g} / \mathrm{cm}^{3}$ pozwoliło na wyznaczenie współczynnika przeliczeniowego: $V_{p}=0,01089 \cdot I_{k o r} \mathrm{~mm} /$ rok.

\section{Wyniki badań}

\section{Badania mikroskopowe materiału w stanie dostawy}

Badania mikroskopowe przeprowadzone dla stopu w stanie dostawy wykazały, że stop charakteryzował się występowaniem fazy AIFeSiMn z obecnością takich pierwiastków jak $\mathrm{Cu}, \mathrm{Zn}$ oraz $\mathrm{Cr}$. Stwierdzono także obecność pojedynczych wydzieleń pierwotnej fazy $\mathrm{Zn}_{2} \mathrm{Mg}(\eta)$ (rys. 1). Interpretację tych faz, niemożliwych do wykrycia metodą dyfrakcji rentgenowskiej ze względu na ich małą zawartość objętościową, wykonano na podstawie mikroanalizy składu chemicznego EDX oraz danych literaturowych [2]. Stop znajdował się w stanie obróbki cieplnej T-6, co wskazuje, że w strukturze obecne są również koherentne lub półkoherentne $\mathrm{w}$ stosunku do osnowy wydzielenia fazy wtórnej $\mathrm{MgZn}_{2}\left(n^{\prime}\right)$, niewidoczne w obrazie mikroskopu świetlnego. Stan obróbki cieplnej potwierdza twardość stopu wynosząca w stanie dostawy $112 \pm 2$ HV5. 

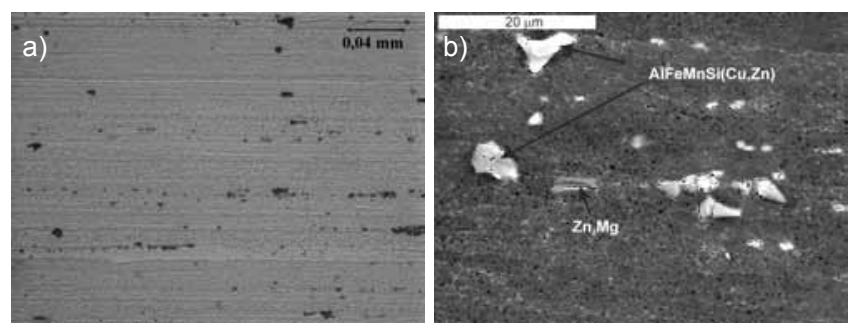

Rys. 1. Mikrostruktura badanego stopu AW 7020 w stanie dostawy, stan trawiony: a) mikroskopia świetlna, b) SEM

Fig 1. Microstructure of AW 7020 alloy as delivered, surface etched: a) light microscopy, b) SEM

\section{Badania mikroskopowe złącza spawanego z zastosowaniem spoiwa 1 (AlMg5)}

W obszarze spoiny, a także w strefie wpływu ciepła nie stwierdzono występowania pęknięć oraz innych wad spawalniczych (rys. 2). Mikrostruktura spoiny była jednorodna i cechowała się strukturą charakterystyczną dla stopów odlewniczych z drobnodyspersyjnymi wydzieleniami faz międzymetalicznych, obecnymi w przestrzeniach międzydendrytycznych roztworu stałego $\alpha$ (rys. 3). Stopień dyspersji tych wydzieleń

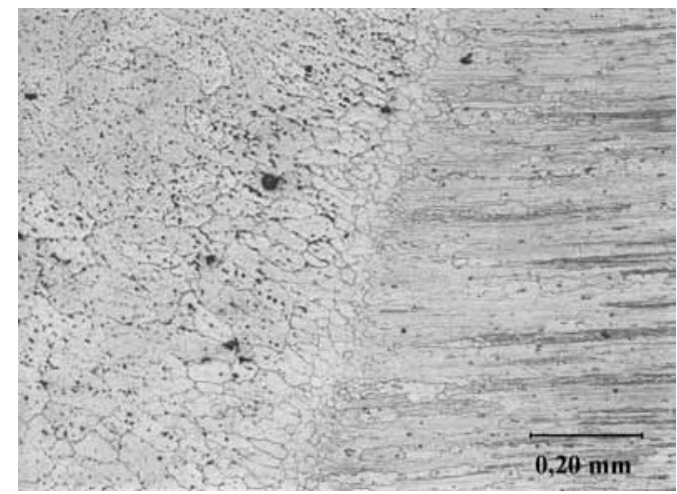

Rys. 2. Mikrostruktura złączy spawanego wykonanego z zastosowaniem spoiwa 1, mikroskopia świetlna, stan trawiony

Fig. 2. Microstructure of welded joint made with the use of filler metal 1 , light microscopy, surface etched

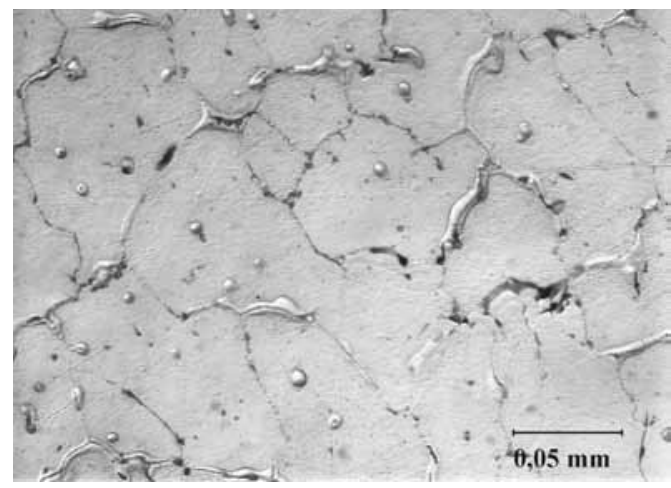

Rys. 3. Mikrostruktura spoiny wykonanej z zastosowaniem spoiwa 1, widoczne nadtapianie równowagowe na granicach ziaren, mikroskopia świetlna, stan trawiony

Fig. 3. Weld microstructure in the welded joint made with the use of filler metal 1 , in the grain boundary visible equilibrium solidification, light microscopy, surface etched

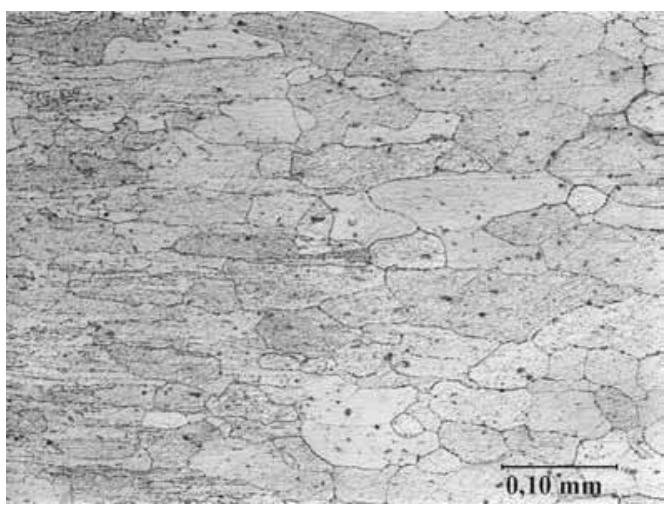

Rys. 4. Mikrostruktura strefy wpływu ciepła w złączu wykonanym z zastosowaniem spoiwa 1, widoczny rozrost ziaren roztworu stałego a mikroskopia świetlna, stan trawiony

Fig. 4. Heat affected zone microstructure in the welded joint made with the use of filler 1, a-phase grain coursing visible, light microscopy, surface etched

związany jest z większą szybkością chłodzenia występującą przy spawaniu niż w warunkach odlewania. W obszarze spoiny stwierdzono występowanie pojedynczych pęcherzy gazowych. Zaobserwowano również nadtapianie równowagowe, które związane jest z rozpuszczaniem faz międzymetalicznych występujących na granicach ziaren, wywołujące segregację składu chemicznego (rys. 3). Prowadzi to do obniżenia temperatury topnienia tych obszarów [19]. W strefie wpływu ciepła (SWC) obserwowano rozrost ziaren roztworu stałego oraz wydzieleń faz umacniających stop wydzieleniowo (rys. 4). Podobne spostrzeżenia odnotowano w [2]. Wyniki badań wytrzymałościowych oraz rozkłady twardości dla uzyskanych połączeń spawanych przedstawiono w [17].

\section{Badania mikroskopowe złącza spawanego z zastosowaniem spoiwa 2 (AlMg4,5Mn)}

W obszarze spoiny, a także w strefie wpływu ciepła połączenia spawanego wykonanego $z$ zastosowaniem spoiwa 2, nie stwierdzono występowania pęknięć oraz innych wad spawalniczych (rys. 5).

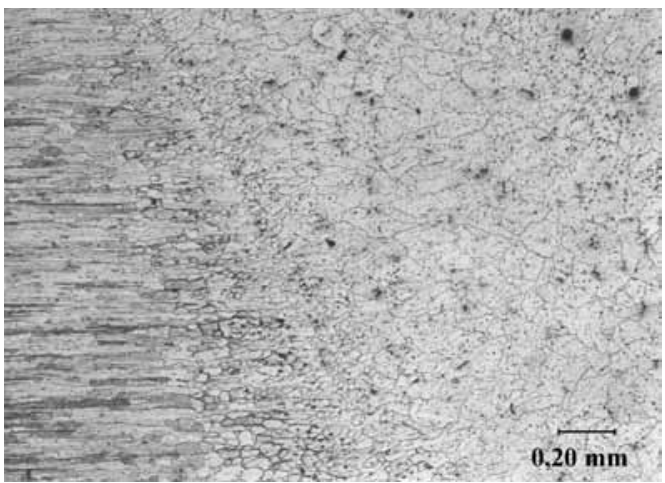

Rys. 5. Mikrostruktura strefy wpływu ciepła w złączu spawanym wykonanym z zastosowaniem spoiwa 2, mikroskopia świetlna, stan trawiony

Fig. 5. Heat affected zone microstructure in the welded joint made with use of filler metal 2 , light microscopy, surface etched 


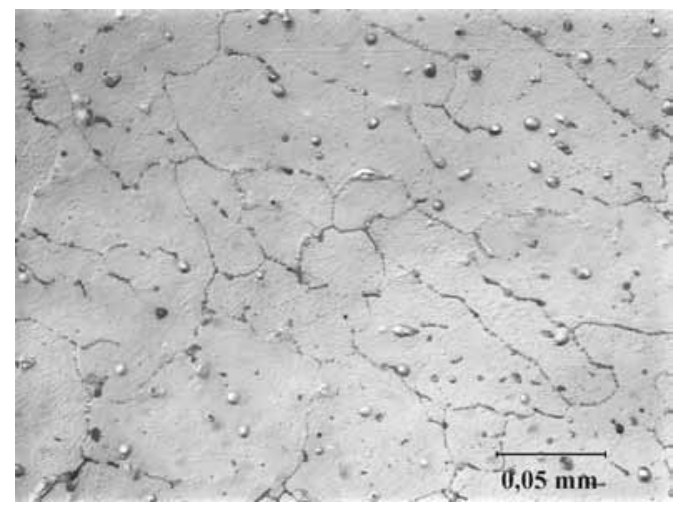

Rys. 6. Mikrostruktura spoiny wykonanej z zastosowaniem spoiwa 2 widoczne nadtapianie równowagowe na granicach ziaren, mikroskopia świetlna, stan trawiony

Fig. 6. Weld microstructure in the welded joint made with the use of filler metal 2 , in the grain boundary visible equilibrium solidification, light microscopy, surface etched

W SWC zaobserwowano rozrost ziaren roztworu stałego a. Mikrostruktura spoiny cechowała się strukturą dendrytyczną z występującymi w przestrzeniach międzydendrytycznych roztworu stałego $\alpha$ drobnodyspersyjnymi wydzieleniami faz międzymetalicznych. W jej obszarze stwierdzono występowanie pojedynczych pęcherzy gazowych. Podobnie jak w połączeniach spawanych z zastosowaniem spoiwa 1 obserwowano nadtapianie równowagowe faz międzymetalicznych w obszarze spoiny (rys. 6). Wyniki prób wytrzymałościowych oraz rozkłady twardości dla uzyskanych złączy spawanych przedstawiono w [17].

\section{Badania mikroskopowe złącza spawanego z zastosowaniem spoiwa 3 (AISi5)}

Dla złączy wykonanych z zastosowaniem spoiwa AISi5 stwierdzono w obszarze spoiny występowanie licznych rzadzizn (rys. 7). Mikrostruktura spoiny

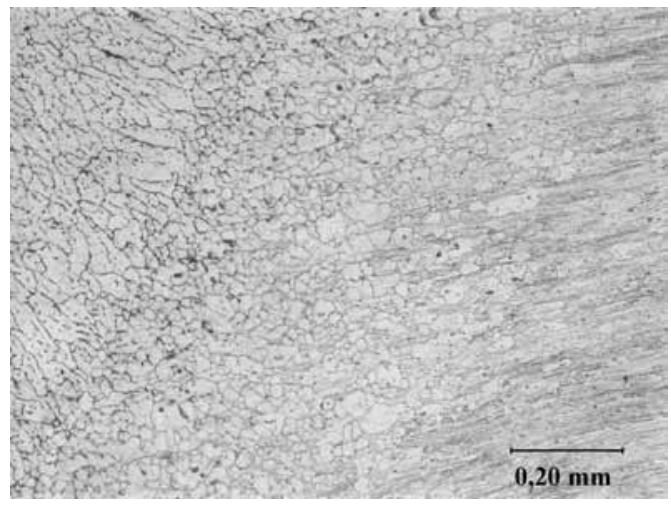

Rys. 7. Mikrostruktura złącza spawanego wykonanego z zastosowaniem spoiwa 3, mikroskopia świetlna, stan trawiony

Fig. 7. Microstructure of welded joint made with the use of filler metal 3, light microscopy, surface etched

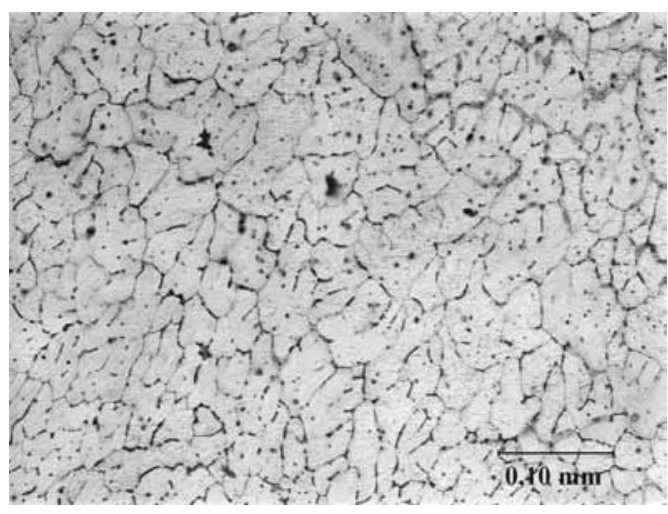

Rys. 8. Mikrostruktura spoiny w złączu spawanym wykonanym z zastosowaniem spoiwa 3, widoczne drobnodyspersyjne wydzielenia faz międzymetalicznych w przestrzeniach roztworu stałego mikroskopia świetlna, stan trawiony

Fig. 8. Weld microstructure in welded joint made with the use of filler 3 , visible fine-dispersion particles of intermetallic phases in the solid solution, light microscopy, surface etched

cechowała się strukturą dendrytyczną z drobnodyspersyjnymi wydzieleniami obecnymi w przestrzeniach międzydendrytycznych roztworu stałego $\alpha$ (rys. 8). W SWC zaobserwowano rozrost ziaren roztworu stałego a (rys. 7). Wyniki prób wytrzymałościowych oraz rozkłady twardości dla uzyskanych złączy spawanych przedstawiono w [17].

\section{Badania elektrochemiczne}

Na rysunku 9 zestawiono przykładowe krzywe polaryzacyjne uzyskane dla próbek pobranych z obszaru spoin wykonanych połączeń spawanych. W tablicy II podano średnie wartości parametrów elektrochemicznych, uzyskane na podstawie trzech pomiarów wykonanych dla każdego z badanych połączeń. Uzyskane wartości oporu polaryzacji $\mathrm{R}_{\mathrm{p}}$ określające szybkość zmian korozyjnych wykazują dla poszczególnych spoiw niewielkie zróżnicowanie. Najwyższe wartości oporu polaryzacji uzyskano dla spoiwa AIMg5, natomiast najniższe dla AISi5. Podobnie kształtują się

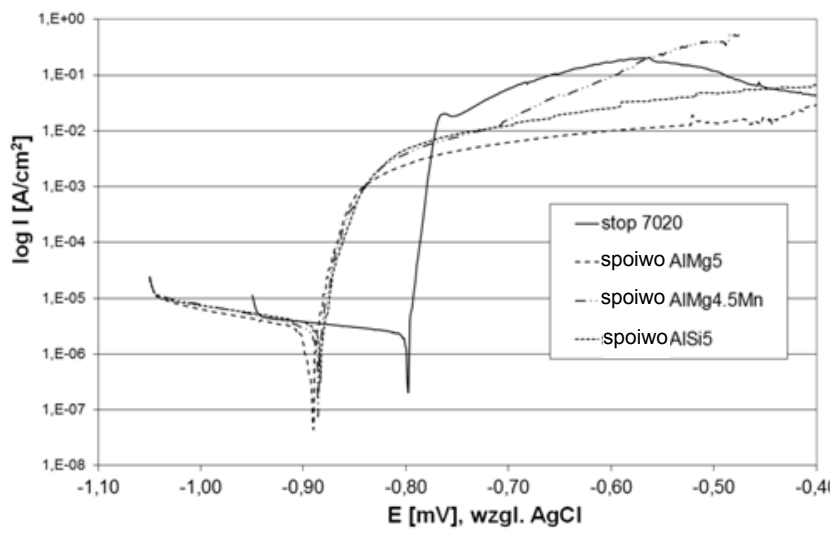

Rys. 9. Przykładowe krzywe polaryzacyjne uzyskane dla stopu AW 7020 oraz dla próbek pobranych z obszaru spoiny wykonanych złączy spawanych

Fig. 9. Example of polarization curves obtained for AW 7020 alloy and weld selected from welded joint 
Tablica II. Zestawienie parametrów elektrochemicznych dla próbek pobranych z obszaru spoiny - stop AW 7020

Table II. Electrochemical parameters of samples of weld metal - AW 7020 alloy

\begin{tabular}{|l|c|c|c|c|c|}
\hline \multicolumn{1}{|c|}{ Parametr } & $\begin{array}{c}\mathrm{E}_{\mathrm{o}} \\
(\mathrm{I}=0) \\
\mathrm{mV}\end{array}$ & $\begin{array}{c}\mathrm{E}_{\mathrm{kor}} \\
\mathrm{mV}\end{array}$ & $\begin{array}{c}\mathrm{I}_{\mathrm{kor}} \\
\mu \mathrm{A} / \mathrm{cm}^{2}\end{array}$ & $\begin{array}{c}\mathrm{R}_{\mathrm{p}} \\
\mathrm{k} \Omega \cdot \mathrm{cm}^{2}\end{array}$ & $\begin{array}{c}\mathrm{V}_{\mathrm{p}} \\
\mathrm{mm} / \mathrm{rok}\end{array}$ \\
\hline Stop AW 7020 & -808 & -803 & 6,43 & 0,58 & 0,07 \\
\hline Elektroda 1 AlMg5 & -888 & -880 & 2,43 & 2,32 & 0,03 \\
\hline $\begin{array}{l}\text { Elektroda 2 } \\
\text { AlMg4,5Mn }\end{array}$ & -893 & -881 & 9,01 & 1,02 & 0,09 \\
\hline Elektroda 3 AISi5 & -894 & -883 & 10,2 & 0,89 & 0,11 \\
\hline
\end{tabular}

wartości zużycia korozyjnego $V_{p}$. Najniższa szybkość korozji powinna być obserwowana dla złącza wykonanego z zastosowaniem spoiwa z magnezem AlMg5, natomiast najwyższa - dla spoiwa z krzemem. Uzyskane wartości gęstości prądów dla badanych spoin są do siebie zbliżone i pozostają w korelacji z wartością parametru $R_{\mathrm{p}}$, tj. im niższa wartość gęstości prądu korozji, tym wyższa wartość oporu polaryzacji.

Wszystkie spoiny wykonane z wykorzystaniem spoiw AlMg5, AlMg4,5Mn i AISi5 charakteryzują się również zbliżoną wartością potencjału korozyjnego. Jest ona niższa od potencjału korozyjnego materiału rodzimego, dla stopu AW 7020 wynoszącego -803 mV. Ta różnica potencjałów ( $w$ przybliżeniu $80 \mathrm{mV}$ ) jest wystarczająca do wystąpienia korozji galwanicznej. Powoduje to utworzenie w złącza spawanym makroobszarów o odmiennym potencjale elektrochemicznym i nie zapewnia ochrony spoiny.

\section{Badania mikroskopowe po badaniach elektrochemicznych}

Wykonano obserwacje mikroskopowe próbek po badaniach elektrochemicznych. W przypadku połączeń spawanych wykonanych z zastosowaniem spoiw z magnezem obserwowano zbliżony charakter zniszczeń korozyjnych po badaniach elektrochemicznych (rys. 10, 11). Roztwarzaniu ulegał roztwór stały $\alpha$, co świadczy o anodowym charakterze (w stosunku do osnowy) obecnych w mikrostrukturze wydzieleń.

Szczególnie niekorzystne zachowanie korozyjne obserwowano w przypadku złącza spawanego wykonanego $z$ zastosowaniem jako spoiwa stopu aluminium z krzemem. Również w tym złącza spawanym obecność faz międzymetalicznych sprzyja silnemu roztwarzaniu roztworu stałego a wokół tych wydzieleń (rys. 12). Stopy serii 7000 wykazują znaczną podatność na korozję międzykrystaliczną. Taki układ morfologiczny mikrostruktury, jak w przypadku połączenia spawanego wykonanego $\mathrm{z}$ zastosowaniem spoiwa z krzemem, charakteryzujący się wytworzeniem ciągłej otoczki faz międzymetalicznych na granicach ziaren, sprzyja jej wystąpieniu [18].

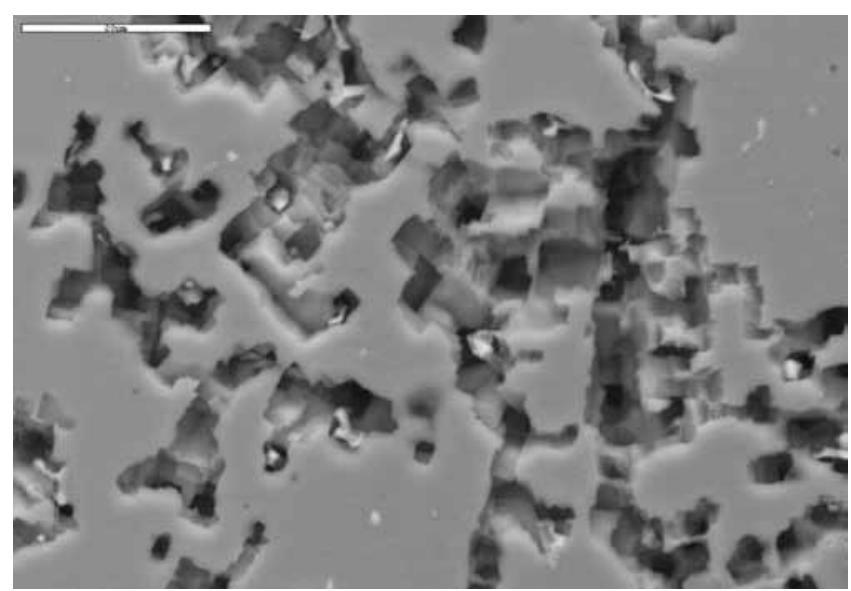

Rys. 11. Powierzchnia obszaru spoiny 2 po badaniach elektrochemicznych, widoczne roztwarzanie roztworu stałego a wokół wydzieleń faz międzymetalicznych, SEM

Fig. 11. Surface of weld metal 2 after electrochemical test, visible a-phase solid solution digestion around intermetallic phases, SEM

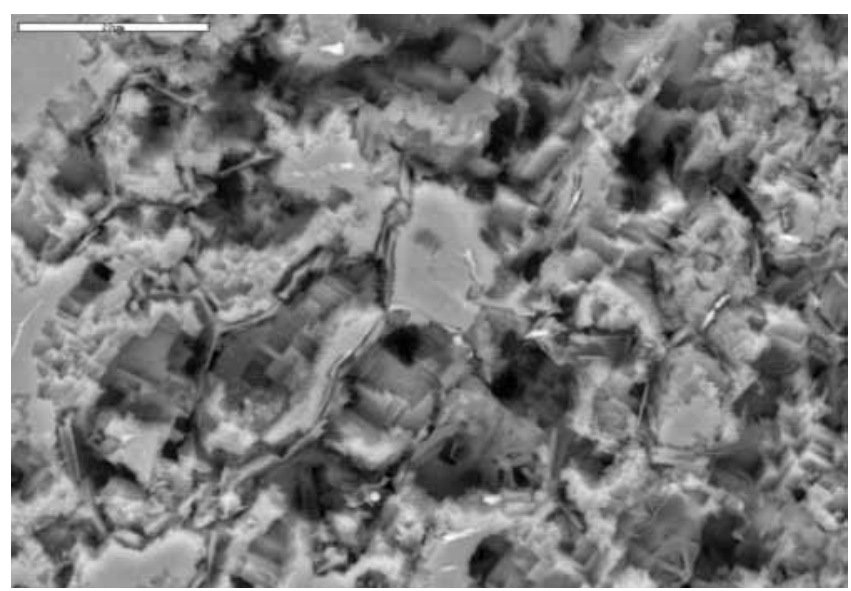

Rys. 12. Powierzchnia obszaru spoiny 3 po badaniach elektrochemicznych, widoczne roztwarzanie roztworu stałego a wokół wydzieleń faz międzymetalicznych tworzących ciągłą otoczkę po granicach ziaren, SEM

Fig. 12. Surface of weld metal 3 after electrochemical test, visible a-phase solid solution digestion around intermetallic phases are continuous through grain boundaries, SEM

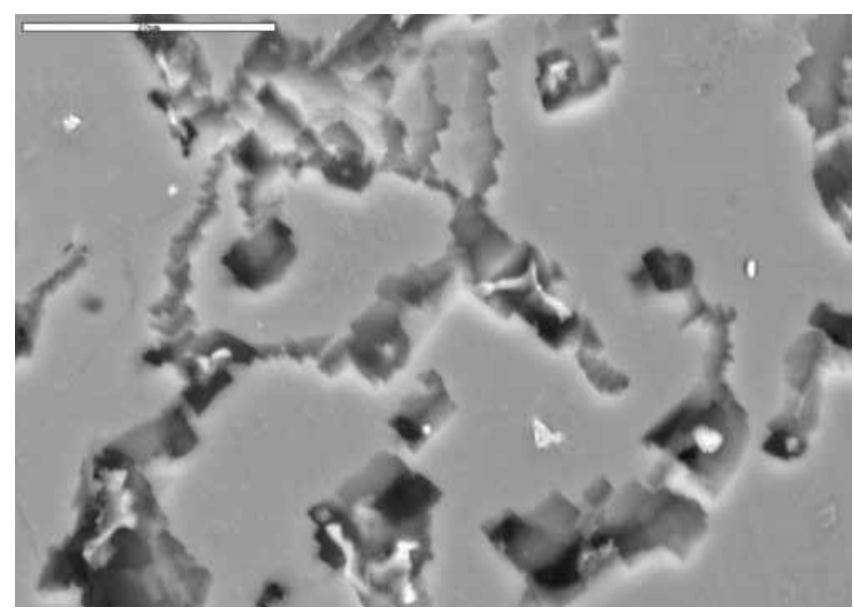

Rys. 10. Powierzchnia obszaru spoiny 1 po badaniach elektrochemicznych, widoczne roztwarzanie roztworu stałego a wokół wydzieleń faz międzymetalicznych, SEM

Fig. 10. Surface of weld metal 1 after electrochemical test, visible a-phase solid solution digestion around intermetallic phases, SEM 


\section{Podsumowanie}

W ramach pracy wykonano złącza spawane z zastosowaniem trzech elektrod o składzie wg normy PN-EN ISO 18273:2007: Materiały dodatkowe do spawania. Druty elektrodowe, druty i pręty do spawania aluminium i jego stopów. Klasyfikacja. Celem prowadzonych badań była ocena odporności korozyjnej złącza spawanych stopu AW 7020 z zastosowaniem trzech spoiw: AlMg5, AlMg4,5Mn i AISi5. Ze względu na korozję, najkorzystniejsze jest zastosowanie jako spoiwa materiału o składzie chemicznym zbliżonym do materiału rodzimego. Zapewnia to uzyskanie zbliżonej wartości potencjału elektrochemicznego w materiale rodzimym i obszarze spoiny. Warto zwrócić uwagę, że norma ta nie przewiduje stosowania nowych spoiw dla stopów serii 7000 . W praktyce spotyka się zatem próby łączenia stopu AW 7020 tradycyjnymi elektrodami objętymi ww. normą, tj. stopami aluminium z magnezem lub krzemem.

W wyniku przeprowadzonych badań zauważono istotne zmiany w parametrach elektrochemicznych dla poszczególnych mikroobszarów wykonanych połączeń spawanych. Wszystkie badane połączenia spawane wykazywały zbliżoną i bardziej ujemną od materiału rodzimego wartość potencjału korozyjnego oraz potencjału obwodu otwartego. Powstające różnice w wartościach potencjałów korozyjnych są na tyle istotne, że może to prowadzić do tworzenia się makroogniw korozyjnych i sprzyjać wystąpieniu korozji galwanicznej. Nie zapewnia to ochrony anodowej badanych połączeń spawanych i sprzyja intensywnej korozji stosunkowo nieznacznej powierzchni spoiny.

Badania powierzchni próbek po badaniach elektrochemicznych wykazały, że w przypadku połączeń spawanych wykonanych z zastosowaniem spoiwa z magnezem obserwowano zbliżony charakter zniszczeń korozyjnych. W obszarze spoiny roztwarzaniu ulegał roztwór stały $\alpha$, co świadczy o anodowym charakterze (w stosunku do osnowy) obecnych w jej mikrostrukturze wydzieleń. Szczególnie niekorzystne zachowanie korozyjne zauważono w przypadku połączenia spawanego wykonanego z zastosowaniem jako spoiwa stopu aluminium z krzemem. Obecność faz międzymetalicznych w postaci ciągłej otoczki faz międzymetalicznych po granicach ziaren sprzyja silnemu roztwarzaniu roztworu stałego a wokół tych wydzieleń. Stopy serii 7000 wykazują znaczną podatność na korozję międzykrystaliczną, a taki układ morfologiczny mikrostruktury, występujący w obszarze spoiny złączy spawanych wykonanych z zastosowaniem spoiwa z krzemem, sprzyja jej wystąpieniu.

\section{Literatura}

[1] Dudzik K., Czechowski M.: The properties of AIZn5Mg1 (AW7020 ) alloys welded by new technology friction stir welding Journal of KONES, 2008, vol. 15, no. 3, s. 115-120.

[2] Ma. T. den Ouden, G.: Softening behaviour of Al-Zn-Mg alloys due to welding. Materials Science and Engineering $A$, 1988 vol. A226, s. $198-204$.

[3] Andreatta F., Lohrengel M.M, Terryn H., de Wit J.H.W.: Electrochemical characterisation of aluminium AA7075-T6 and solution heat treated AA7075 using a micro-capillary cell. Electrochimica Acta, 2003, vol. 48, s. 3239-3247.

[4] Andreatta F., Terryn H., de Wit J.H.W.: Effect of solution heat treatment on galvanic coupling between intermetallics and matrix in AA7075-T6. Corrosion Science, 2003, vol. 45, s. 1733-1746.

[5] Kwiatkowski L.: Podatność na korozję i skuteczność aktualnych metod ochrony przed korozją stopów aluminium w budownictwie. Inżynieria powierzchni, 2009, 4, s. 24-33.

[6] Nowak M., Opyrchał M., Motyka M., Płonka B., Rajda M.: Korozja ultradrobnoziarnistych stopów aluminium serii 2xxx i 7xxx. Rudy i metale nieżelazne, 2010, 7, s. 514-517.

[7] Meng Q., Frankel G.S.: Effect of Cu content on corrosion behavior of $7 x x x$ series aluminum alloys. Journal of The Electrochemical Society, 2004, 151, 5, s. B271-B283.

[8] Ura-Bińczyk E., Bałkowiec A.Z., Mikołajczyk Ł., Lewandowska M., Kurzydłowski K.J.: Wpływ wielkości ziarna na odporność korozyjną stopu aluminium 7475 . Ochrona przed korozja, 2011, 2, s. 44-47.

[9] Podrez-Radziszewska M., Haimann K.: Badania porównawcze odporności na korozję elektrochemiczna wybranych stopów aluminium z serii 2xxx, 5xxx i 7xxx. Ochrona przed korozją, r. 54 , nr 7 , s. $440-443$.

[10] Ma T., den Ouden G.: Softening behaviour of Al-Zn-Mg alloys due to welding. Materials Science and Engineering $A$, 1998, vol. A226, s. 198-204.

[11] Lech-Grega M., Hawryłkiewicz S., Richert M., Szymański W.: Structural parameters of 7020 alloy after heat treatment simulating the welding process. Materials Characterization, 2001, vol. 46, s. 251-257.

[12] Temmar M., Hadji M., Sahraoui T.: Effect of post-weld aging treatment on mechanical properties of Tungsten Inert Gas welded low thickness 7075 aluminium alloy joints. Materials and Design, 2011, vol. 32, s. 3532-3536.

[13] Hwan T.K., Soo W.N.: Soldification cracking susceptibility of high strenght aluminium alloy weldment. Scripta Materialia, 1995, vol. 34, no. 7, s. 1139-1145.

[14] Janaki Ram G.D., Mitra T.K., Shankar V., Sundaresan S.: Microstructural refinement through inoculation of type 702 $\mathrm{Al}-\mathrm{Zn}-\mathrm{Mg}$ alloy welds and its effect on hot cracking and tensile properties. Journal of Materials Processing Technology, 2003, vol. 142, s. 174-181.

[15] Jha A.K., Murty S.V.S.N., Diwakar V., Sree Kumar K.: Metallurgical analysis of cracking in weldment of propellant tank. Engineering Failure Analysis, 2002, vol. 10, s. 265-273.

[16] Liu C., Northwood D.O., Bhole S.D.: Tensile fracture behavior in $\mathrm{CO} 2$ laser beam welds of 7075-T6 aluminium alloy. Materials and Design, 2004, vol. 25, s. 573-577.

[17] Podrez-Radziszewska M.: Weldability problems of the technical AW7020 alloy. Manufacturing Technology, 2011, vol. 11, s. 59-66.

[18] Kuźnicka B., Podrez-Radziszewska M.: Correlation between microstructural evolution in heat affected zone and corrosion behaviour of Al-Cu alloy. Archives of Metallurgy and Materials 2008 , vol. 53 , iss. 3 , s. 933-938

[19] Tasak E.: Metalurgia spawania. Wydawnictwo JAK Andrzej Choczewski. Kraków 2008.

Dr inż. Marzena M. Lachowicz (poprzednio: Marzena PodrezRadziszewska) jest stypendystką Ministra Nauki i Szkolnictwa Wyższego dla wybitnego młodego naukowca. 